\title{
Contribution of rennet and starter to proteolysis in Iranian UF white cheese
}

\author{
Javad HeSARI ${ }^{\mathrm{a}, \mathrm{d}}$, Mohammad R. EHSANI ${ }^{\mathrm{b}}$, Asghar KHOSROSHAHIc, \\ Paul L.H. MCSWEENEYd* \\ a Department of Food Science and Technology, Tabriz University, P.O. Box 51666, Tabriz, Iran \\ $\mathrm{b}$ Department of Food Science and Technology, Tehran University, Tehran, Iran \\ c Department of Food Science and Technology, Urmia University, Urmia, Iran \\ ${ }^{\mathrm{d}}$ Department of Food and Nutritional Sciences, University College, Cork, Ireland
}

Received 24 February 2006 - Accepted 12 May 2006

\begin{abstract}
The relative contributions of rennet and starter to proteolysis during the storage of ultrafiltered (UF) Iranian white cheese were investigated. In the experimental design used, starter and rennet were, in separate treatments, omitted and gluconic acid- $\delta$-lactone was used for acidification of starter-free samples. The experimental treatments used did not have significant effects on composition. Omission of rennet in manufacture significantly reduced proteolysis during ripening of UF white cheese, and caused differences in peptide profiles determined by both urea-polyacrylamide gel electrophoresis and reversed-phase HPLC; omission of starter had a considerably smaller effect on these parameters. In cheeses made without rennet, noticeable casein degradation was not observed suggesting little contribution of indigenous proteinases to proteolysis during the ripening of UF Iranian white cheese. Both rennet and starter contributed indirectly or directly to production of free amino acids in UF white cheese and omission of either of these agents strongly reduced production of FAA during ripening.
\end{abstract}

Iranian white cheese / ultrafiltration / rennet / starter / proteolysis

摘要 - 凝乳酶和发酵剂对超滤伊朗白干酪蛋白质水解的作用。系统地研究了以超滤法生产 的伊朗白干酪在成熟期间凝乳酶和发酵剂对蛋白质水解的作用。采用了 3 种制备干酪方法, 第一组使用发酵剂和凝乳酶（对照组），第二组使用凝乳酶但用 $\delta$ 一葡萄糖酸内酯作为酸 化剂, 第三组只使用发酵剂。试验结果表明, 三种制备方法对白干酪的化学组成没有显著 的影响。未经凝乳酶处理的白干酪在成熟过程中蛋白质水解程度明显降低, 尿素一聚丙烯 酰胺凝胶电泳和高效液相色谱测定结果也表明肽的组成有明显的差异; 使用凝乳酶但未加 发酵剂的白干酪样品也存在这种趋势, 但是这种作用程度非常低。未经凝乳酶处理的白干 酪中酪蛋白几乎未发生水解, 这说明在干酪成熟过程中内源蛋白酶对蛋白质水解作用非常 小。在白干酪成熟过程中, 凝乳酶和发酵剂均能直接和间接的影响游离氨基酸的产生, 省 略两者中任何一种都会使干酪中游离氨基酸的含量明显减少。

伊朗白干酪 / 超滤 / 凝乳酶 / 发酵剂 / 蛋白质水解

\footnotetext{
* Corresponding author (通讯作者): p.mcsweeney@ucc.ie
} 
Résumé - Contribution de la présure et des ferments à la protéolyse du fromage iranien de type pâte fraîche fabriqué par ultrafiltration (UF). Les contributions relatives de la présure et des ferments à la protéolyse du fromage iranien de type pâte fraîche fabriqué par ultrafiltration ont été étudiées au cours du stockage. L'expérimentation comportait respectivement un essai sans présure et un essai sans ferment. L'acidification des fabrications sans ferment a été réalisée à l'aide de glucono-delta-lactone. Les différents traitements n'avaient pas d'effet significatif sur la composition. L'omission de la présure au cours de la fabrication réduisait de façon significative la protéolyse au cours de la maturation du fromage à pâte fraîche fabriqué par UF, et provoquait des différences dans les profils peptidiques observés aussi bien par électrophorèse sur gel polyacrylamide-urée que par chromatographie liquide en phase inverse ; l'omission de ferment avait un effet considérablement moins marqué sur ces paramètres. Dans les fromages fabriqués sans présure, aucune dégradation perceptible de la caséine n'a été observée, suggérant ainsi une faible contribution des protéases endogènes à la protéolyse au cours de la maturation du fromage iranien de type pâte fraîche fabriqué par UF. La présure et les ferments contribuaient tous deux indirectement ou directement à la production des acides aminés libres dans le fromage UF à pâte fraîche et l'omission de l'un ou de l'autre de ces agents réduisait fortement la production des acides aminés libres au cours de la maturation.

fromage à pâte fraîche iranien / ultrafiltration / présure / ferment / protéolyse

\section{INTRODUCTION}

Proteolysis is the most complex and important event that occurs during the ripening of a great number of cheese varieties [11] and strongly affects the sensory properties of ripened cheeses [15]. Proteolytic enzymes from the rennet and starter are the principal proteolytic agents acting during cheesemaking and ripening [10]. Primary proteolysis of cheese proteins may be defined as those changes to $\alpha_{s 1^{-}}$and $\beta$ casein and peptides therefrom and is mainly the result of the action of residual coagulant and indigenous proteinases (i.e., plasmin, and perhaps cathepsin D or other somatic cell proteinases) [15] while the complex proteolytic and peptidolytic systems of microorganisms, both starter and nonstarter, are responsible for secondary proteolysis [5, 43]. Rennet is an enzymatic preparation that coagulates milk and is a key factor for cheesemaking; the most common enzyme in rennet preparations is chymosin. Its hydrolytic action at the 105-106 bond of bovine $\kappa$-casein results in the formation of the coagulum. Moreover, it is one of the main proteolytic factors involved in cheese ripening [32]. The proteinases of rennet are mainly responsible for the initial proteolysis of the caseins in cheese and modify its texture by slowly degrading $\alpha_{\mathrm{s} 1}$ and, to a lesser extent, $\beta$-caseins, which are responsible for forming the framework of the cheese matrix, and produce precursors of sapid compounds [19] but make only a minor and indirect contribution to the liberation of free amino acids [35].

Although starters are usually added to milk for acidification during cheesemaking, their proteolytic activity during cheese ripening is well known [13]. The main components of the proteolytic system of LAB are proteinases (mainly lactocepin, although intracellular proteinases have been reported; [2]), amino acid and peptide transport systems, and a range of intracellular peptidases. The primary role of lactocepin is to degrade the caseins to provide short peptides to support the growth of the lactococcal cells in milk. However, its role in cheese ripening is different. Peptides isolated from Cheddar cheese, the $\mathrm{N}$ - or C-terminus of which corresponds to the specificity of lactocepin, do not contain a major chymosin or plasmin cleavage site [11], suggesting that chymosin or plasmin act first and that lactocepin then hydrolyses the resulting intermediate-sized peptides [49]. In contrast to traditional cheeses, in which only a small part of the rennet activity added to the milk remains in the curd after manufacture [16], in UF white cheese all the rennet is retained in the curd since it is added to the retentate. On the other hand, whey proteins are present in UF cheeses at high concentration and may inhibit chymosin, microbial rennets $[18,20]$ and probably other proteinases and peptidases [22]. UF cheeses are characterized by slower proteolysis and production 
of amino acids during ripening [21] which influence the development of cheese flavor and texture. The available information about the rennet and starter activities in UF cheeses is very limited. Likewise the contribution of rennet and starter has not been studied in Iranian UF white cheese. In this study, an attempt was made to produce rennet-free and starter-free UF white cheeses; in the later case using gluconic acid- $\delta$-lactone as an acidulant as described by Wium et al. [52] and proteolysis was studied during ripening.

\section{MATERIALS AND METHODS}

\subsection{Cheesemaking}

Experimental UF white cheeses were made in three trials on separate days. The retentate was prepared by Iran Dairy Industry Inc., Pegah Co (Tabriz, Iran) and used for production of Iranian UF white cheese. Raw milk of high microbial quality was standardized to $3.5 \%$ fat, and after bactofugation in two steps, pasteurized at $72{ }^{\circ} \mathrm{C}$ for $15 \mathrm{~s}$ and then ultrafiltered at $50^{\circ} \mathrm{C}$. The membrane cartridges were of the spiral wound type (no UFPH20 Invensys APV, Silkeborg, Denmark) and the membrane had a nominal molecular weight cut-off of approximately $20 \mathrm{~kg} \cdot \mathrm{mol}^{-1}$ with a surface area of $16.9 \mathrm{~m}^{2}$. The ultrafiltration unit was operated at an inlet pressure of 5.3 bar and an outlet pressure of 1.7 bar. The retentate was pasteurized at $78^{\circ} \mathrm{C}$ for $60 \mathrm{~s}$ and then cooled to $35^{\circ} \mathrm{C}$. Three types of cheeses were produced: control samples by adding starter $(1 \%)$ and standard bovine rennet (Renco, Eltham, New Zealand) $\left(30 \mathrm{mg} \cdot \mathrm{kg}^{-1}\right)$; samples without starter acidified by gluconic acid- $\delta$-lactone (GDL, 3.6\%) but containing rennet $\left(30 \mathrm{mg} \cdot \mathrm{kg}^{-1}\right)$; and samples without rennet but containing starter $(1 \%)$. A mixture of mesophilic (G3 mix, composed of Lc. cremoris and Lc. lactis) and thermophilic (Joghurt 709, composed of Str. thermophilus and Lb. delbrueckii subsp. bulgaricus) cultures (both prepared commercially by Laboratorium Visby, Tender Aps, Denmark) in the ratio 7:1, was used as starter. The retentate was adjusted with permeate to $340 \mathrm{~g}$ dry matter $\cdot \mathrm{kg}^{-1}$ as described by Wium et al. [52] and then immediately filled $(450 \mathrm{~g})$ into containers and left to coagulate at $30^{\circ} \mathrm{C}$ room for 60 min. A parchment paper was placed on top of the coagulum and dry salt $(3 \%)$ was added. The containers were sealed with aluminum foil. Salt gradually adsorbed moisture from curd and a layer of brine formed around cheeses in the containers. Cheese packs were held at $26-28{ }^{\circ} \mathrm{C}$ for $24 \mathrm{~h}$ and then transferred to a cool room $\left(8{ }^{\circ} \mathrm{C}\right)$; the next day was considered as the first day of ripening and the samples were ripened for three months. One cheese of each trial was sampled at 1,30, 60, and 90 days during ripening.

\subsection{Analytical methods}

\subsubsection{Chemical composition}

Cheeses were analysed for moisture by the oven drying method at $102 \pm 2{ }^{\circ} \mathrm{C}$ [24], salt by a potentiometric method [12], fat by Gerber method [25], total protein and $\mathrm{pH}$ 4.6-soluble nitrogen by the macro-Kjeldahl method [23]. The $\mathrm{pH}$ of the cheese was measured by direct insertion of an electrode (PHC3031-9, Radiometer Analytical, Copenhagen, Denmark) into grated cheese. All analyses were performed in triplicate and results reported as mean \pm standard deviation.

\subsubsection{Assessment of proteolysis}

The $\mathrm{pH}$ 4.6-insoluble and -soluble fractions of the cheese samples were obtained by a slight modification of the procedure of Kuchroo and Fox [27] as described by Sousa and McSweeney [48]. The pH 4.6soluble fraction was fractionated into $70 \%$ ethanol-soluble (small, hydrophilic peptides) and -insoluble (large, hydrophobic peptides) fractions as described by Reville and Fox [44]. Urea-polyacrylamide gel electrophoresis (PAGE) of the $\mathrm{pH}$ 4.6insoluble fraction of the cheese was performed using a Protean II XI vertical slabgel unit (Bio-Rad Laboratories Ltd., Watford, UK) according to the method of Andrews [4] as modified by Shalabi and Fox [47]. 
Table I. Composition of 1-day-old experimental ultrafiltered (UF) Iranian white cheeses, results are presented as average of data from three independent replicate trials \pm standard deviations.

\begin{tabular}{lccccc}
\hline Cheeses & $\mathrm{pH}$ & Moisture $(\%)$ & Protein $(\%)$ & Fat $(\%)$ & $\mathrm{NaCl}(\%)$ \\
\hline Control & $4.52 \pm 0.05$ & $60.65 \pm 1.01$ & $11.27 \pm 0.25$ & $17.85 \pm 0.35$ & $3.13 \pm 0.11$ \\
Starter-free & $4.54 \pm 0.02$ & $59.67 \pm 0.90$ & $12.25 \pm 0.32$ & $17.92 \pm 0.41$ & $3.10 \pm 0.08$ \\
Rennet-free & $4.52 \pm 0.03$ & $59.71 \pm 0.88$ & $11.35 \pm 0.51$ & $18.25 \pm 0.42$ & $3.07 \pm 0.15$ \\
L.S.D. ${ }^{1}$ & 0.061 & 2.321 & 1.74 & 1.88 & 0.30
\end{tabular}

${ }^{1}$ L.S.D. = least significant difference.

The gels were stained directly with Coomassie Brillant Blue G250, as described by Blakesley and Boezi [6]. Peptide profiles of the ethanol-insoluble and-soluble fractions of the $\mathrm{pH}$ 4.6-soluble extracts were determined by RP-HPLC using a Varian System (Varian Associates Inc., Walnut Creek, CA, USA), as described by Hayaloglu et al. [19]. Total free amino acids (FAA) were determined by the trinitrobenzenesulphonic acid (TNBS) assay as described by Polychroniadou [41]. Concentrations of individual free amino acids were determined using a Beckman model 6300 amino acid analyser equipped with a Beckman model P-N $338052 \mathrm{Na}^{+}$cation-exchange column $(12 \times$ $0.4 \mathrm{~cm}$ ) according the method described by Fenelon et al. [9].

\subsubsection{Statistical Analysis}

A randomised complete block design which incorporated three treatments (control cheeses, cheeses made without starter and cheeses made without rennet) and three blocks (trials) was used and significance of differences in results was estimated by using 1-way ANOVA (significance level $P<0.05)$. The RP-HPLC chromatograms of ethanol (70\%)-insoluble and -soluble fractions of the $\mathrm{pH}$ 4.6-soluble fractions were analysed by multivariate statistical analysis. Principal component analysis (PCA) was applied to the HPLC variables (peak heights) using a covariance matrix [42]. The data for PCA were obtained by taking peaks heights as variables and preprocessed using a logistic function [39]; after this step, processed data consisted of classes of retention time (retention classes) wherein peak heights were accumulated using the distance from center of class as a weight. Hierarchical cluster analysis (HCA) was performed using the between-groups linkage cluster method. Statistical analysis was carried out using SPSS, Version 11 for Windows 98 (SPSS Inc., Chicago, IL, USA).

\section{RESULTS AND DISCUSSION}

\subsection{Composition}

The compositions of 1-day old experimental Iranian UF white brined cheeses are shown in Table I. There were no significant differences between the gross compositions of the different cheeses. These results showed that changes to cheesemaking protocols used to give rennet-free and starterfree cheeses did not have significant effect on the gross composition of cheeses as reported by other workers for various cheeses [26, 29, 52].

\subsection{Level of pH 4.6-soluble nitrogen as \% of total nitrogen (pH 4.6- SN/TN)}

The levels of $\mathrm{pH} 4.6-\mathrm{SN} / \mathrm{TN}$ in experimental UF Iranian white cheeses during ripening are shown in Figure 1. The levels of $\mathrm{pH}$ 4.6-SN/TN in the control UF cheese were significantly higher than the samples made without starter and rennet at 15,30 and 60 days of ripening $(P<0.05)$. The level of $\mathrm{pH}$ 4.6-SN is an index of ripening [31] and produced mainly by the action of enzymes from rennet and plasmin [35]. While formation of $\mathrm{pH}$ 4.6-SN in rennet-free 


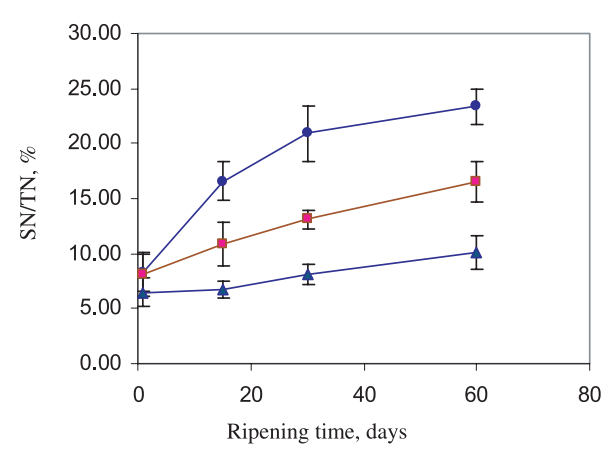

Figure 1. Formation of $\mathrm{pH} 4$.6-soluble nitrogen as a percentage of total nitrogen $(\mathrm{SN} / \mathrm{TN})$ in control (৩), starter-free $(\boldsymbol{\square})$ and rennet-free $(\boldsymbol{\Delta})$ UF Iranian white cheeses during ripening.

cheese occurred very slowly in the cheeses made without starter, levels of $\mathrm{pH}$ 4.6-SN increased through the action of residual rennet, although it occurred at a lower rate than that in the control cheeses. These results showed that rennet is mainly responsible for formation of $\mathrm{pH}$ 4.6-SN during ripening of Iranian UF white cheese, although starter also has a noticeable effect on its production. Mara and Kelly [29] reported that Quarg prepared without the addition of rennet had lower levels of proteolysis than was observed for control cheeses made with added rennet. This is also consistent with the findings of Zakrzewski et al. [53] and Shakeel-Ur-Rehman et al. [46].

\subsection{Urea-PAGE}

Urea-PAGE electrophoretograms of the $\mathrm{pH}$ 4.6-insoluble fraction of experimental UF white cheeses of Trial 1 after 30 and 60 days of ripening are shown in Figure 2. Results of other trials were similar (not shown). There were some notable differences in electrophoretic patterns between the three cheese types. While degradation of $\beta$-casein was negligible, $\alpha_{\mathrm{s} 1}$-casein was hydrolysed to $\alpha_{\mathrm{s} 1}-\mathrm{CN}$ (f24-199). In starterfree cheese, degradation of $\alpha_{\mathrm{s} 1}$-casein was also seen, although to lower extent compared to the control samples. In samples made without the use of rennet, $\alpha_{\mathrm{s} 1}$-casein remained nearly intact and $\alpha_{\mathrm{s} 1}-\mathrm{CN}$ (f24199) was not produced after 1 and 2 months of ripening. These observations indicate that initial proteolysis of the caseins in Iranian UF white cheese is carried out mainly by enzymes from the coagulant; however, starter enzymes may contribute to a small extent to initial proteolysis. Many authors (e.g., [1, 19, 37, 45]) have reported the resistance of $\beta$-casein to hydrolysis during the ripening of many cheese varieties. When animal rennet is used as a coagulant in internal bacterially ripened cheese varieties, proteolysis of $\beta$-casein is less than that of $\alpha_{\mathrm{s} 1^{-c a s e i n}}$ [13]. Alichanidis et al. [3] reported that the high $\mathrm{NaCl}$ concentration and low $\mathrm{pH}$ of Feta cheese markedly reduced the degradation of $\beta$-casein by the coagulant and plasmin, but the hydrolysis

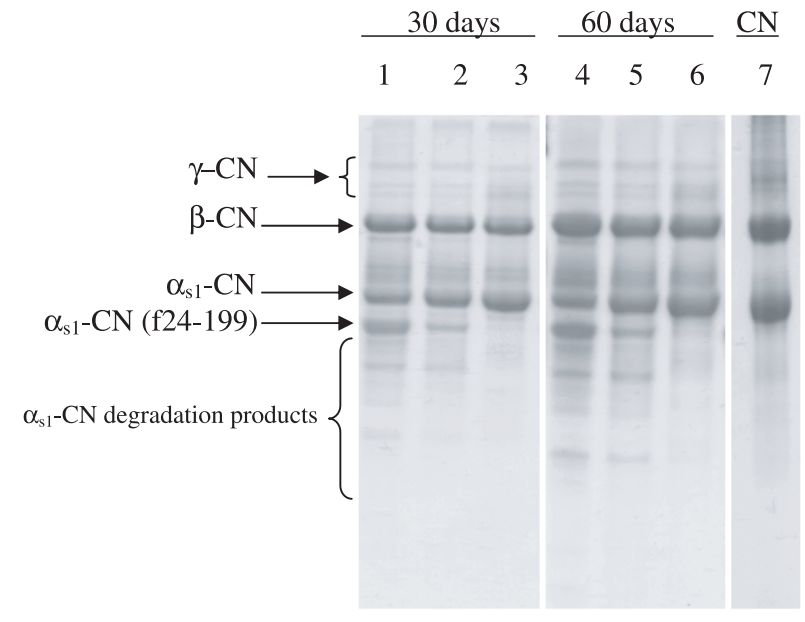

Figure 2. Urea polyacrylamide gel electrophoretograms of experimental UF Iranian white brined cheeses after 30 and 60 days of ripening. Lane 1, 4: control; lane 2, 5: starterfree cheeses; lane 3, 6: rennetfree cheeses; lane 7: sodium caseinate. 
of $\alpha_{s 1}$-casein was not inhibited. Vicente et al. [50] reported that the effects of the starter bacteria on primary proteolysis of Idiazabal cheese were dependent on the casein fractions and peptides produced by the coagulant. In our study, the lack of notable degradation of caseins in rennet-free cheeses confirms this hypothesis. Similar observations were reported by Moatsou et al. [33] for Feta cheese. Primary proteolysis of caseins in cheese is generally due mainly to the activity of chymosin (on $\alpha_{s 1-}$ casein) and of plasmin (on $\beta$-casein) [17] but they are not the sole active proteolytic agents [29]. Wium et al. [52] observed degradation of $\alpha_{\mathrm{s} 1}$-casein in UF Feta cheese made without rennet and ascribed it to cathepsin D activity. The continued absence of $\alpha_{\mathrm{s} 1}$-I-casein in our rennet-free Iranian UF white cheese suggests little contribution of the milk acid proteinase cathepsin D, which should exert a chymosin-like action at the $\mathrm{pH}$ of white cheese. This is probably due to extensive inactivation of the enzyme by pasteurization, combined with the relatively short storage period of UF white cheese. These results are in agreement with the studies of Mara and Kelly [29] who reported the lack of degradation of $\alpha_{\mathrm{s} 1^{-}}$ casein in rennet-free Quarg.

\subsection{RP-HPLC}

RP-HPLC peptide profiles of the ethanol-soluble and -insoluble subfractions of the $\mathrm{pH}$ 4.6-soluble extracts from experimental UF white cheeses of Trial 1 after 60 days of ripening are shown in Figure 3; results of other trials were similar (not shown). Noticeable qualitative and quantitative differences were found between peptides profiles of $(70 \%)$ ethanol-soluble and -insoluble fractions of control samples and cheeses produced without starter and rennet. In both subfractions, the early eluting peaks (retention times of 4-8 min) generally include many free amino acids. Using whey protein standards, it was confirmed that the peaks eluting at ca. 53 and $57 \mathrm{~min}$ corresponded to $\alpha$-lactalbumin and $\beta$-lactoglobulin, respectively. As shown in Figure $3 \mathrm{~B}$, the main differences between peptide profiles of ethanol-insoluble fractions of control and starter-free cheeses were in the region of the chromatogram with retention time of 10-30 min. The concentration of peptides eluting in this region for starter-free samples were lower than that in the control cheeses. The peaks that elute early in the RP-HPLC chromatograms are comprised mainly of hydrophilic peptides and those that elute later are hydrophobic peptides. Hence, it appeared that starter was mostly effective in the production of hydrophilic peptides. Cheeses prepared without rennet yielded the simplest chromatograms with peptides at lowest concentration (Fig. 3B) most notably in the region with retention time of $10-50 \mathrm{~min}$.

To investigate differences between the chromatographic profiles of ethanol-insoluble subfractions of experimental UF white cheeses, PCA was performed on peak height data [42] and the results are shown in Figure 4. The first three principal components (PCs) explained $84.22 \%$ of the total variance (TV). The peak categories, identified by their retention time, most correlated with PC1 (that accounted for the $59.79 \%$ of the TV) and their factor loadings (between brackets) were peak categories 14 (0.956), 43 (0.953), 36 (0.952), 38 (0.946), $49(0.917)$ and 7 (0.916). PC2 explained $14.46 \%$ of the TV and the peaks categories most correlated with this $\mathrm{PC}$ and their factor loadings were 56 (0.942), $46(0.931)$ and 57 (0.931). HCA highlighted closely related clusters which were indicated as ovals on the score plots (Fig. 4A). Samples appeared to be distributed in two main groups, one including control samples $(\mathrm{C})$ and the other one comprising starter-free cheese $(\mathrm{S})$ and rennet-free cheeses $(\mathrm{R})$, separated based on the peptide profiles of their ethanol (70\%)insoluble fractions. The second group was almost divided to two subgroups including starter-free and rennet-free cheeses, suggesting that the activities of enzymes from both starter and rennet affect the ethanolinsoluble peptide profile of UF white cheese. PCA was also applied to the RPHPLC data from the $70 \mathrm{~mL} \cdot 100 \mathrm{~mL}^{-1}$ ethanol-soluble fractions from the 60-day old cheese samples in order to explore the distribution of the samples according to their 


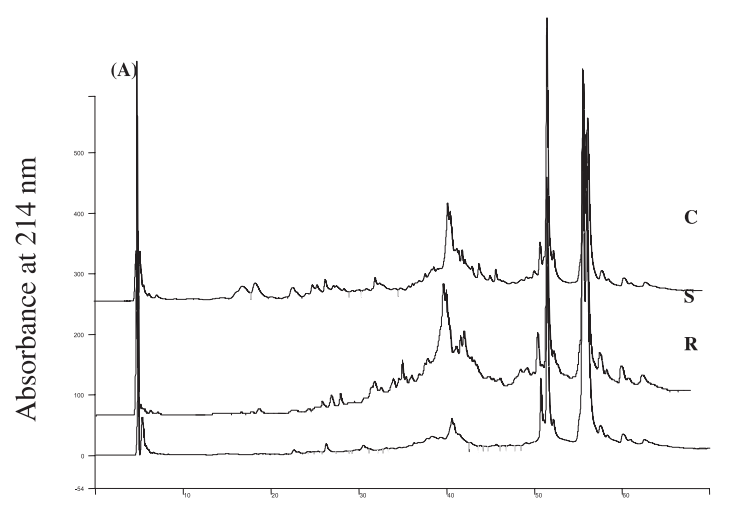

Retention time, $\min$

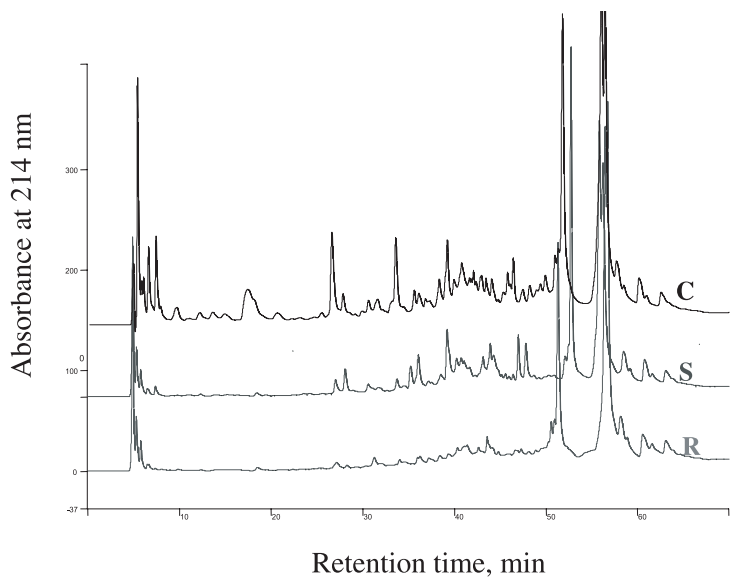

Figure 3. Reverse phase-HPLC profiles of (70\%) ethanol-insoluble (A) and (70\%) ethanol-soluble (B) fractions of experimental control (C), starter-free (S) and rennet-free (R) UF Iranian white cheeses of Trial 1 at 2 months of ripening.

peptide profiles; the score plot from the PCA is shown in Figure 4B. The first three PC explained $81.61 \%$ of the TV. PC1 explained $48.613 \%$ of the TV and the peak categories most correlated with this PC and their factor loadings were $34(0.955), 7$ (0.936), 27 (0.933) and 32 (0.918). PC2 accounted for $18.95 \%$ of TV and the peaks most correlated with this $\mathrm{PC}$ and their factor loadings were 33 (0.97), $52(0.965)$ and 50 $(0.955)$. As is shown in Figure 4B, HCA distributed the samples in three main groups, including control samples (C), starter free cheeses (S) and rennet free cheeses (R). As PC1 explained most the variation between the control and experimental cheeses, suggesting that the peptides which contributed to the variation between these samples mostly eluted in the chromatogram at retention times shorter than $35 \mathrm{~min}$ and thus could be considered hydrophilic $[14,30,38]$. 
(A)
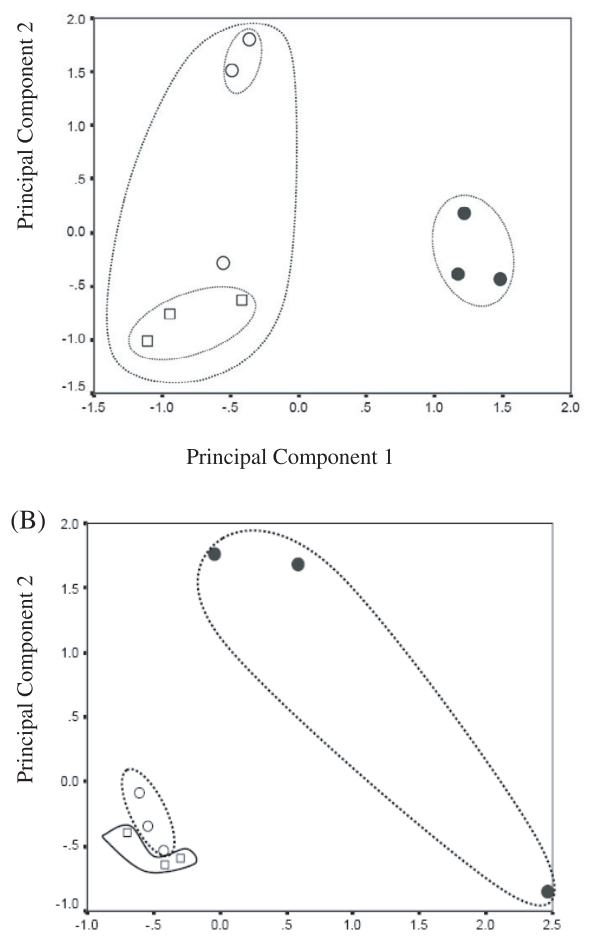

Principal Component 1

Figure 4. Score plots obtained from principal component analysis and results of hierarchical cluster analysis (dotted lines) of data from reverse phase-HPLC profiles of ethanol-insoluble (a) and -soluble (b) subfractions of three replicate experimental UF Iranian white cheesemaking trials including control $(\bullet)$, starter-free $(\bigcirc)$ and rennet-free $(\square)$ cheeses at 2 months of ripening.

\subsection{Total and individual free amino acids}

As is shown in Table II, the total free amino acid content of UF white cheeses made without starter or rennet was significantly lower than in control samples after 1 , 2 and 3 months of ripening $(P<0.05)$. Although there was no significant difference between total free amino acid levels of 30 day-old starter-free and rennet-free cheeses, after 2 and 3 months of ripening, the total free amino acid content of rennetfree cheeses were significantly lower than that of starter-free cheeses $(P<0.05)$. Figure 5 shows levels of individual free amino acids in experimental Iranian UF white cheeses of Trial 1 at 2 months of ripening; results of other trials were similar (not shown). Levels of all individual amino acids were also higher in control cheese than in starter-free and rennet-free samples. The data obtained from analysis of individual free amino acids in 60 day-old samples were used as variables for PCA and the results are shown in Figure 6. Also illustrated on the score plots are clusters obtained from HCA of free amino acid data. The samples were grouped into two main clusters: one including control samples $(C)$ and the other one comprising starter-free cheese (S) and rennet-free cheeses (R). The first two principal components (PCs) explained $94.51 \%$ of the total variance (TV). PC1 explained $75.5 \%$ of the TV and the amino acids most correlated with this PC and their factor loadings were histidine (0.997), threonine (0.996), leucine (0.996), aspartic acid (0.991), valine (0.984) and lysine (0.968). In control UF white cheeses,

Table II. Total levels of free amino acids during the ripening of experimental UF Iranian white cheeses determined by the the trinitrobenzenesulphonic acid (TNBS) assay. The results are means of data from three independent replicate trials \pm standard deviations.

\begin{tabular}{lccc}
\hline Cheeses & \multicolumn{3}{c}{ mg Leucine $100 \mathrm{~g}^{-1} \mathrm{DM}$} \\
\cline { 2 - 4 } & 1 month & 2 months & 3 months \\
\hline Control & $4.96 \pm 0.34^{\mathrm{a}}$ & $7.21 \pm 0.60^{\mathrm{a}}$ & $9.07 \pm 0.33^{\mathrm{a}}$ \\
Starter free & $2.09 \pm 0.12^{\mathrm{b}}$ & $3.24 \pm 0.10^{\mathrm{b}}$ & $4.68 \pm 0.18^{\mathrm{b}}$ \\
Rennet free & $1.96 \pm 0.19^{\mathrm{b}}$ & $2.82 \pm 0.08^{\mathrm{c}}$ & $3.94 \pm 0.11^{\mathrm{c}}$ \\
\hline
\end{tabular}

a,b,c Values within a column not sharing a common letter differ, $P<0.05$. 


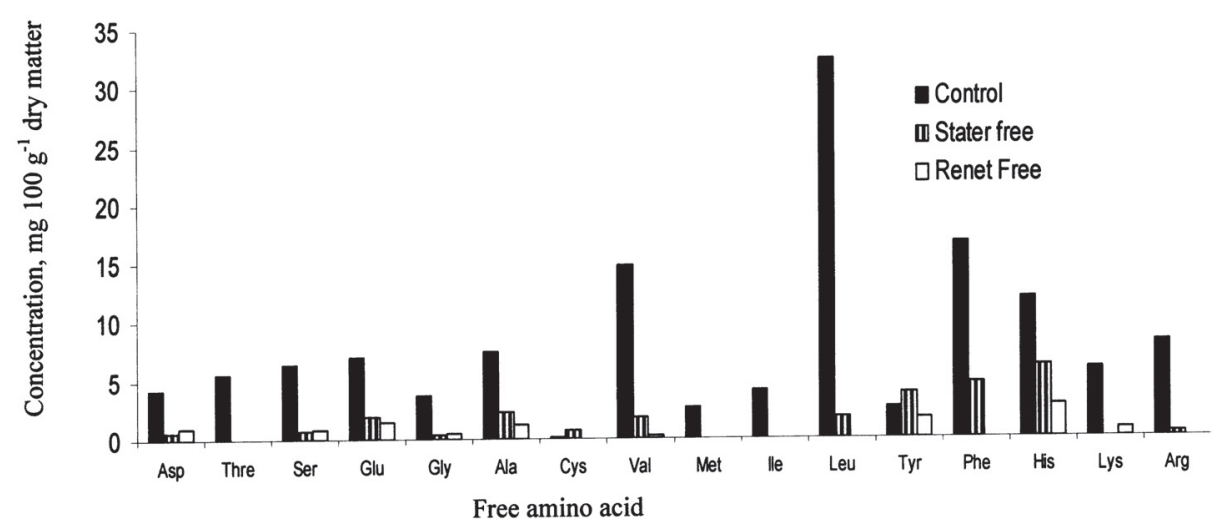

Figure 5. Levels of individual free amino acids in experimental UF Iranian white cheeses of Trial 1 at 2 months of ripening.

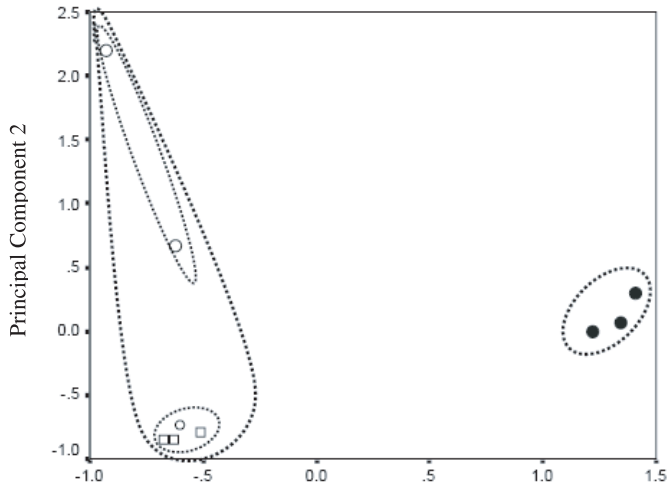

Principal Component 1
Figure 6. Score plots obtained from principal component analysis and hierarchical cluster analysis (dotted lines) of data of individual free amino acids of experimental UF Iranian white cheese including control $(\bullet)$, starterfree $(\bigcirc)$ and rennet-free $(\square)$ cheeses of Trial 1 at 2 months of ripening the dominant free amino acids were leucine, phenylalanine, valine and histidine, while in starter-free cheeses, dominant free amino acids were histidine, phenylalanine, tyrosine and valine, while in rennet-free cheeses histidine, tyrosine, glutamic acid and valine were dominant (Fig. 5). The composition of the amino acid fraction and the relative proportions of individual amino acids are thought to be important for the development of cheese flavour [7, 34]. Certain amino acids (e.g., methionine) have been considered indices of cheese ripening [8]. Several authors have reported that proteinases from rennet mainly hydrolyze caseins yielding high molecular weight fractions and essentially no free amino acids [36]. Pitchard and Coolbear [40] reported that the high molecular weight peptides released first by the rennet proteinases were the substrates for the proteolytic activity of the starter proteinases, leading to low molecular weight peptides and free amino acids. On the other hand, addition of lactic acid bacteria (LAB) as a starter produced a higher content of short-chain peptides and free amino acids during cheese ripening [28]. Vicente et al. [51] reported that the release of the free amino acids during ripening was strongly affected by the type of 
starter added to the cheeses, and that this effect varied markedly with the rennet used for cheesemaking.

\section{CONCLUSION}

In the UF white cheese made in this study, the proteolytic agents during ripening including rennet and starter enzymes were effective in proteolysis during ripening. The results indicated that rennet is the principal ripening agent in primary proteolysis of UF white cheese, while starter enzymes contributed to a lesser degree to the formation of $\mathrm{pH}$ 4.6-soluble nitrogen and degradation of $\alpha_{\mathrm{s} 1}$-casein. Both factors had notable effect on secondary proteolysis as studied by ethanol-soluble and -insoluble peptide profiles and levels of free amino acids of UF white cheeses. Omission of rennet or starter causes an obvious reduction in the levels of peptide and free amino acids produced during ripening.

\section{REFERENCES}

[1] Abd El-Salam M.H., Alichanidis E., Zerfiridis G.K., Domiati and Feta type cheeses, in: Fox P.F. (Ed.), Cheese: Chemistry, physics and microbiology, Volume 2, Major cheese groups, 2nd edn., Chapman \& Hall, London, UK, 1993, pp. 301-335.

[2] Akuzawa R., Yokoyama K., Matsuishi M., Ohitani A., Isolation and partial characterization of intracellular proteinases in Lactococcus lactis ssp. lactis IAM 1198, J. Dairy Sci. 73 (1990) 3385-3392.

[3] Alichanidis E., Anifantakis E.M., Polychroniadou A., Nanou M., Suitability of some microbial coagulants for Feta cheese manufacture, J. Dairy Res. 51 (1984) 141-147.

[4] Andrews A.T., Proteinases in normal bovine milk and their action on caseins, J. Dairy Res. 50 (1983) 45-55.

[5] Awad S., Luthi-Peng Q.Q., Puhan Z., Influence of coagulants and starter bacteria on proteolysis and sensory quality of Gouda type cheese from buffalo milk, Sci. Techn. Latt.-Cas. 50 (1999) 405-430.

[6] Blakesley R.W., Boezi J.A., A new staining technique for proteins in polyacrylamide gels using Coomassie Brilliant Blue G250, Anal. Biochem. 82 (1977) 580-581.
[7] Engels W.J.M., Visser S., Isolation and comparative characterization of components that contribute to the flavour of different cheese types, Neth. Milk Dairy J. 48 (1994) 127140.

[8] Farkye N., Fox P.F., Objective indices of cheese ripening, Trends Food Sci. Technol. 1 (1990) 37-40.

[9] Fenelon M.A., O’Connor P., Guinee T.P., The effects of fat content on the microbiology and proteolysis in Cheddar cheese during ripening, J. Dairy Sci. 83 (2000) 2173-2183.

[10] Fox P.F., Stepaniak L., Enzymes in cheese technology, Int. Dairy J. 3 (1993) 509-530.

[11] Fox P.F., McSweeney P.L.H., Proteolysis in cheese during ripening, Food Rev. Int. 12 (1996) 457-509.

[12] Fox P.F., Potentiometric determination of salt in cheese, J. Dairy Sci. 46 (1963) 744-745.

[13] Fox P.F., Law J., McSweeney P.L.H., Wallace J., Biochemistry of cheese ripening, in: Fox P.F. (Ed.), Cheese: Chemistry, physics and microbiology, Volume 1: General aspects, 2nd edn., Chapman \& Hall, London, UK, 1993, pp. 389-438.

[14] González de Llano D., Polo M.C., Ramos M., Study of proteolysis in artisanal cheeses: High performance liquid chromatography of peptides, J. Dairy Sci. 78 (1995) 1018-1024.

[15] Grappin R., Rank T.C., Olson N.F., Primary proteolysis of cheese proteins during ripening: a review, J. Dairy Sci. 68 (1985) 531540 .

[16] Guinee T.M., Wilkinson M.G., Rennet coagulation and coagulants in cheese manufacture, J. Soc. Dairy Technol. 45 (1992) 94104.

[17] Hannon J.A., Sousa M.J., Lillevang S., Sepulchre A., Bockelmann W., McSweeney P.L.H., Effect of defined-strain surface starters on the ripening of Tilist cheese, Int. Dairy J. 14 (2004) 871-880.

[18] Harper J., Iyer M., Knighton D., Lelievre J., Effects of whey proteins on the proteolysis of Cheddar cheese slurries (a model for the maturation of cheeses made from ultrafiltered milk), J. Dairy Sci. 72 (1989) 333-341.

[19] Hayaloglu A.A., Guven M., Fox P.F., Hannon J.A., McSweeney P.L.H., Proteolysis in Turkish white-brined cheese made with defined strains of Lactococcus, Int. Dairy J. 14 (2004) 599-610.

[20] Hayes M.G., McSweeney P.L.H., Kelly A.L., The influence of native and heat denatured whey proteins on enzyme activity 2 . Chymosin, Milchwissenschaft 57 (2002) 264-267. 
[21] Hesari J., Ehsani M.R., McSweeney P.L.H., The influence of whey proteins on peptidase activities of Lactococcus lactis spp. cremoris AM1, Milchwissenschaft 61 (2006) 316-318.

[22] Hickey M.W., van Leeuwen H., Hillier A.J., Jago G.R., Amino acid accumulation in Cheddar cheese manufactured from normal and ultrafiltered milk, Aust. J. Dairy Technol. 38 (1983) 110-115.

[23] IDF, Determination of the protein content of processed cheeses products, IDF Standard 25, Int. Dairy Fed., Brussels, Belgium, 1964.

[24] IDF, Determination of the total solid content (cheese and processed cheese). IDF Standard 4a, Int. Dairy Fed., Brussels, Belgium, 1982.

[25] IIRS, Determination of the percentage of fat in cheese. Irish Standard 69, Dublin, Institute for Industrial Research and Standards, Ireland, 1995.

[26] Karakus M., Alperden I., Effect of starter composed of various species of lactic acid bacteria on quality and ripening of Turkish White pickled cheese, Lebensm.-Wiss. Technol. 28 (1995) 404-409.

[27] Kuchroo C.N., Fox P.F., Soluble nitrogen in Cheddar cheese: comparison of extraction procedures, Milchwissenschaft 37 (1982) 331-335.

[28] Lee B.H., Laleye L.C., Simard R.E., Munsch M.H., Halley R.A., Influence of homofermentative Lactobacillus on the microflora and soluble nitrogen components in Cheddar cheese, J. Food Sci. 55 (1990) 391-397.

[29] Mara O., Kelly A.L., Contribution of milk enzymes, starter and rennet to proteolysis during storage of Quarg, Int. Dairy J. 8 (1999) 973-979.

[30] McSweeney P.L.H., Fox P.F., Lucey J.A., Jordan K.N., Cogan T.M., Contribution of the indigenous microflora to the maturation of Cheddar cheese, Int. Dairy J. 3 (1993) 613-634.

[31] McSweeney P.L.H., Fox P.F., Chemical methods for the characterization of proteolysis in cheese during ripening, Lait 77 (1997) 41-76.

[32] Moatsou G., Moschopoulou E., Aik Georgala, Zoidou E., Kandarakis I., Kaminarides S., Anifantakis E., Effect of artisanal liquid rennet from kids and lambs abomasa on the characteristics of Feta cheese, Food Chem. 88 (2004) 517-525.

[33] Moatsou G., Massouras T., Kandarikis I., Anifantakis E., Evaluation of proteolysis during the ripening of traditional Feta cheese, Lait 82 (2002) 601-611.
[34] Molina E., Ramos M., Alonso L., LopezFandino R., Contribution of low molecular weight water soluble compounds to the taste of cheeses made of cow's, ewe's and goat's milk, Int. Dairy J. 9 (1999) 613-621.

[35] O'Keeffe R.B., Fox P.F., Daly C., Contribution of rennet and starter proteases to proteolysis in Cheddar cheese, J. Dairy Res. 43 (1976) 97-107.

[36] O'Keeffe R.B., Fox P.F., Daly C., Proteolysis in Cheddar cheese: role of coagulant and starter bacteria, J. Dairy Res. 45 (1978) 465-477.

[37] O’Mahony J.A., Sousa M.J., McSweeney P.L.H., Proteolysis in miniature Cheddartype cheeses made using blends of chymosin and Cynara cardunculus proteinases as coagulant, Int. J. Dairy Technol. 56 (2003) $52-$ 58.

[38] Picón A., Gaya P., Medina M., Nuflez M., The effect of liposome encapsulation of chymosin derived by fermentation on Manchego cheese ripening, J. Dairy Sci. 7 (1994) 6-23.

[39] Piaino P., Parente E., McSweeney P.L.H., Anew approach for preprocessing of chromatographic data and chemometrical analysis of proteolytic profiles of cheese extracts, J. Agric. Food Chem. 52 (2004) 6904-6911.

[40] Pitchard G.G., Coolbear T., The physiology and biochemistry of the proteolytic system in lactic acid bacteria, FEMS Microbiol. Rev. 12 (1993) 179-206.

[41] Polychroniadou A., A simple procedure using trinitrobenzenesulphonic acid for proteolysis in cheese, J. Dairy Res. 55 (1988) 585-596.

[42] Pripp A.H., Shakeel-Ur-Rehman, McSweeney P.L.H., Fox P.F., Multivariate statistical analysis of peptide profiles and free amino acids to evaluate effects of single-strain starters on proteolysis in miniature Cheddar-type cheeses, Int. Dairy J. 9 (1999) 473-479.

[43] Rank T.C., Grappin R., Olson N.F., Secondary proteolysis of cheese during ripening: a review, J. Dairy Sci. 68 (1985) 801-805.

[44] Reville W.J., Fox P.F., Soluble protein in Cheddar Cheese, a comparison of analytical methods, Irish J. Food Sci. Technol. 2 (1978) 67-76.

[45] Sarantinopoulos P., Kalantzopoulos G., Tsakalidou E., Effect of Enterococcus faecium on microbiological, physicochemical and sensory characteristics of Greek Feta cheese, Int. J. Food Microbiol. 76 (2002) 93-105.

[46] Shakeel-Ur-Rehman, Feeney E.P., McSweeney P.L.H., Fox P.F., Inhibition of residual coagulant in cheese using pepstatin, Int. Dairy J. 8 (1998) 987-992. 
[47] Shalabi S.I., Fox P.F., Electrophoretic analysis of cheese, comparison of methods, Irish J. Food Sci. Technol. 11 (1987) 135-151.

[48] Sousa M.J., McSweeney P.L.H., Studies on the ripening of Cooleeney, an Irish farmhouse Camembert-type cheese, Irish J. Agric. Food Res. 40 (2001) 83-95.

[49] Upadhyay V.K., McSweeney P.L.H., Magboul A.A.A., Fox P.F., Proteolysis in Cheese during Ripening, in: Fox P.F., McSweeney P.L.H., Guinee T.P, Cogan T.M. (Eds.), Cheese: Chemistry, physics and microbiology, Vol. 1: General aspects, 3rd edn., Elsevier Applied Science, Amsterdam, The Netherlands, 2004, pp. 391-433.

[50] Vicente M.S., Ibanez F.C., Barcina Y.R., Barron L.J.R., Casein breakdown during ripening of Idiazabal cheese: Influence of starter and rennet type, J. Sci. Food Agric. 81 (2000) 210-215.

[51] Vicente M.S., Ibáňez F.C., Barcina Y., Barron L.J.R., Changes in the free amino acid content during ripening of Idiazabal cheese: influence of starter and rennet type, Food Chem. 72 (2001) 309-317.

[52] Wium H., Kristiansen K.R., Qvist K.B., Proteolysis and its role in relation to texture of Feta cheese made from ultrafiltered milk with different amounts of rennet, J. Dairy Res. 65 (1998) 665-674.

[53] Zakrzewski E., Stepaniak L., Abrahamsen R.K., Sørrhaug T., Effect of thermisation on the quality of Quarg, Int. Dairy J. 1 (1991) 199-208. 